\title{
Biosimilar infliximab for the management of rheumatoid arthritis in France: what are the expected savings?
}

\author{
M Beck, ${ }^{1}$ B Michel, ${ }^{1}{ }^{12}$ M-C Rybarczyk-Vigouret, ${ }^{1}$ C Sordet, ${ }^{3}$ J Sibilia, ${ }^{3}$ M Velten ${ }^{4}$
}

'OMEDIT Alsace, Agence Régionale de Santé d'Alsace, Strasbourg, France ${ }^{2}$ Service de PharmacieStérilisation, C.H.R.U. Hôpitaux Universitaires de Strasbourg, Strasbourg, France 3Service de Rhumatologie, C.H.R.U. Hôpitaux

Universitaires de Strasbourg, Strasbourg, France

"Laboratoire d'épidémiologie et de santé publique-

EA3430, Faculté de Médecine, Université de Strasbourg, Strasbourg, France

\section{Correspondence to} Dr Morgane Beck, OMEDIT Alsace, Agence Régionale de Santé, 14, rue du Maréchal Juin, Strasbourg 67084, France; Morgane.BECK@ars.sante.fr

Received 29 January 2016 Revised 3 March 2016 Accepted 7 March 2016 Published Online First 24 March 2016
CrossMark

To cite: Beck M, Michel $B$, Rybarczyk-Vigouret M-C, et al. Eur J Hosp Pharm 2017:24:85-90.
ABSTRACT

Objectives Biosimilar infliximab, the first similar biological medicinal product containing monoclonal antibodies to be commercialised, is likely to contribute to a significant reduction in healthcare costs. We aimed to assess the cost savings potential over 1 year of the use of biosimilar infliximab for the treatment of rheumatoid arthritis (RA) patients in Alsace and in France, in a reallife setting.

Methods The analysis was based on a previously conducted observational study which evaluated the annual cost of the care of patients with RA treated with biological therapies in 2012 in Alsace. Average annual costs to manage RA patients were calculated, taking into account the decrease in the retail price between 2012 and 2015 (as given in the official national price list) and the local negotiated price for biosimilar infliximab. Annual cost savings for different biosimilar prescription scenarios were calculated using 2015 prices.

Results Management of RA patients with biosimilar infliximab was significantly cheaper than with adalimumab or etanercept (€11 907 vs $€ 12981$ and $€ 13551$, respectively). The projected annual cost savings reached $€ 13.6$ million nationally, if all adult RA patients treated with the originator infliximab switched to the biosimilar drug. These savings, if fully reallocated for the treatment of RA, would enable the treatment of 1141 additional patients.

Conclusions The study showed a positive financial impact of introducing biosimilar infliximab for the treatment of RA patients in France. Such savings could contribute to improved patient care by allowing more patients to be treated without more money being spent.

\section{INTRODUCTION}

Biologic treatments have noticeably changed the way rheumatoid arthritis (RA) and some other inflammatory autoimmune diseases are treated. These innovative drugs are now recommended as second-line therapy for the treatment of moderate-to-severe RA after failure of conventional disease-modifying anti-rheumatic drugs (DMARDs), such as methotrexate (MTX). Some of these innovative drugs are also prescribed to adult patients with severe, active and progressive disease not previously treated with MTX or other DMARDs as a first-line therapy. ${ }^{1-6}$ However, they are associated with high procurement costs and considerably increase the direct costs of RA and the economic burden on the healthcare system. ${ }^{7-10}$ Infliximab-a biologic treatment indicated in rheumatology and chronic inflammatory bowel diseases-has proven efficacy and safety. It is the first monoclonal antibody for which a biosimilar drug has been commercialised and was recently launched in France in February 2015.

Biosimilars are 'copies' of authorised biological drugs whose patents have expired. These complex molecules are very similar but not absolutely identical to the reference products, in particular because of differences in production and purification processes. ${ }^{11}$ The European Medicines Agency (EMA) issued guidelines on similar biological medicinal products in 2005, and specific updates for biosimilar drugs containing monoclonal antibodies in 2012, describing all conditions to be met for a new drug to be approved as a biosimilar drug. ${ }^{12}{ }^{13}$ One of the fundamental requirements for assessing biosimilarity is that there are no meaningful differences between the biosimilar and the originator drug in terms of quality, safety and efficacy. To comply with these requirements, biosimilar drugs undergo rigorous characterisation, as was done for the biosimilar infliximab. In PLANETRA, a phase 3 clinical trial, a biosimilar infliximab (CT-P13) and originator infliximab were shown to be equivalent in terms of clinical efficacy as measured by ACR20 (American College of Rheumatology 20) response criteria at week 30 in RA patients with inadequate response to MTX. ${ }^{14}$ In addition, a meta-analysis in 2014 demonstrated there was no significant difference in terms of response and safety between biosimilar infliximab and originator infliximab and other available biological drugs (abatacept, adalimumab, certolizumab, etanercept, golimumab, rituximab and tocilizumab) for the treatment of RA. ${ }^{15}$

Recent market approval of biosimilar infliximab could lead to substantial cost savings. Several reviews have emphasised potential cost savings from the use of biosimilars, ${ }^{16}{ }^{17}$ and some budget impact analyses were performed to quantify these cost reductions. Haustein et al showed that the use of biosimilars in Europe was expected to result in overall cost savings of $€ 11.8$ billion to $€ 33.4$ billion between 2007 and 2020, and of $€ 2.9$ billion to $€ 6.3$ billion in France only. ${ }^{18}$ Other studies have looked at biosimilar infliximab across all indications or restricted to RA, and included a discount rate as part of their assessments. All were based on theoretical models which were specifically designed to evaluate the financial impact. ${ }^{19-23}$

A study was previously conducted to describe and compare costs related to inpatient and outpatient care of RA patients treated with biotherapies in 2012 in Alsace. This observational study was carried out in a real-life setting with the use of 
health claims data, and showed that inpatient care with originator infliximab infusion in hospitals was more expensive than outpatient care with the administration of subcutaneous drugs at home, for example, adalimumab or etanercept (€16480 vs $€ 14116$ and $€ 14338$, respectively). ${ }^{24}$ It seemed important to re-evaluate this study in light of recent data related to biosimilar infliximab.

\section{Objective}

In light of the great changes in biologic therapy that occurred in 2015 with the introduction of biosimilar infliximab, we aimed to assess the potential for cost savings associated with the use of biosimilar infliximab to treat RA patients in Alsace and in France.

\section{METHOD}

The analysis was based on a previously conducted study aimed at estimating the annual cost of care with biological therapies of adult RA patients' in 2012 in Alsace. This observational study was carried out using real-life use and cost data from the health insurance claims databases DCIR (Données de Consommation Inter-Régimes) and PMSI (Programme de Médicalisation des Systèmes d'Information). The viewpoint of the study was that of the French National Health Insurance CNAMTS (Caisse Nationale de l'Assurance Maladie des Travailleurs Salariés). ${ }^{24}$

\section{Costs}

The annual average costs to treat RA patients were calculated, taking into account the decrease in retail prices between 2012 and 2015, as given in the official national price list (table 1), and local price negotiations for biosimilar infliximab. All costs were quoted exclusive of value added tax (VAT). The negotiated price for biosimilar infliximab (Inflectra) was $€ 269.33$, corresponding to a discount of $-38.0 \%$ compared to the national retail prices for originator infliximab and biosimilar infliximab, which were the same. This local price was obtained by the French UniHA joint purchasing organisation in February 2015, and was applied to all hospitals in the region. UniHA has not obtained negotiated prices for adalimumab (Humira), etanercept (Enbrel) or originator infliximab (Remicade). We validated this information by searching for negotiated prices in the PMSI (Programme de Médicalisation des Systèmes d'Information) database, the main source of information on hospital activity and associated expenditure in France. For comparison, the official retail prices (exclusive of VAT) for adalimumab, etanercept, originator infliximab and biosimilar infliximab in the UK, Germany, Spain and Italy are given in table 2.

The percentage reduction was applied to the 2012 RA patients' dataset, thereby enabling the annual average biotherapy cost for a single RA patient to be estimated, and the average cost for annual RA patient care. The latter included the cost of biotherapy acquisition and direct medical and non-medical costs for hospitalisation, consultation with a general practitioner or specialist, subcutaneous injections administered at home by nurses (in case of treatment with adalimumab or etanercept), laboratory tests, radiology examinations and physiotherapy, and transport expenses. These costs were detailed in our previous study. ${ }^{24}$ Costs for transport, laboratory tests and hospitalisation were greater for infliximab than for adalimumab and etanercept (representing $29.0 \%$ of the total cost of RA patient management versus $7.9 \%$ for adalimumab and $9.9 \%$ for etanercept). Costs for biotherapy acquisition were higher for subcutaneous biotherapies (representing $82.4 \%$ of total costs for adalimumab and $79.8 \%$ for etanercept versus $62.8 \%$ for infliximab). Dosing was assumed to be the same for the originator infliximab and biosimilar infliximab, as well as efficacy, side effects and drug monitoring. Only drug acquisition costs were considered to change, with all other direct costs assumed to be the same for originator infliximab and biosimilar infliximab.

Annual cost savings were then estimated in 2015 prices, according to different biosimilar scenarios for possible biosimilar infliximab uptake rates. The savings shown are entirely due to the lower negotiated price for the biosimilar drug compared to the current prices for the originator infliximab and other biological drugs. They do not reflect the significant decrease in the originator infliximab retail price since 2012.

Table 1 Reduction in the retail price (excl. VAT) of adalimumab, etanercept, originator infliximab and biosimilar infliximab since their introduction in France

\begin{tabular}{|c|c|c|c|c|}
\hline Biotherapy & Volume, presentation & $\begin{array}{l}\text { Effective date } \\
\text { of the new retail price }\end{array}$ & $\begin{array}{l}\text { Retail price } \\
\text { (excl. VAT, in } € \text { ) }\end{array}$ & $\begin{array}{l}\text { Reduction in retail price between } \\
2012 \text { and } 2015 \text { (percent decrease) }\end{array}$ \\
\hline $\begin{array}{l}\text { Adalimumab } \\
\text { (Humira) }\end{array}$ & $\begin{array}{l}40 \mathrm{mg} \\
\text { syringe or pen }\end{array}$ & $\begin{array}{l}15 \text { Sep } 2010 \\
1 \text { Feb } 2013 \\
1 \text { Aug } 2013\end{array}$ & $\begin{array}{l}513.45 \\
462.11 \\
443.62 \\
417.01\end{array}$ & $-9.76 \%$ \\
\hline $\begin{array}{l}\text { Etanercept } \\
\text { (Enbrel) }\end{array}$ & $\begin{array}{l}25 \mathrm{mg} \\
\text { syringe } \\
50 \mathrm{mg} \\
\text { syringe or pen }\end{array}$ & $\begin{array}{l}15 \text { Sep } 2010 \\
24 \text { Apr } 2013 \\
1 \text { Mar } 2014 \\
15 \text { Sep } 2010 \\
24 \text { Apr } 2013 \\
1 \text { Mar } 2014\end{array}$ & $\begin{array}{l}126.08 \\
113.47 \\
109.50 \\
105.67 \\
252.16 \\
226.95 \\
219.00 \\
211.34\end{array}$ & $-6.88 \%$ \\
\hline $\begin{array}{l}\text { Originator infliximab } \\
\text { (Remicade) }\end{array}$ & $\begin{array}{l}100 \mathrm{mg} \\
\text { vial }\end{array}$ & $\begin{array}{l}1 \text { Sep } 2009 \\
1 \text { Oct } 2010 \\
1 \text { Jun } 2011 \\
1 \text { Nov } 2014\end{array}$ & $\begin{array}{l}561.00 \\
536.28 \\
509.47 \\
482.67 \\
434.40\end{array}$ & $-10.0 \%$ \\
\hline $\begin{array}{l}\text { Biosimilar infliximab } \\
\text { (Inflectra) }\end{array}$ & $\begin{array}{l}100 \mathrm{mg} \\
\text { vial }\end{array}$ & 27 Jan 2015 & 434.40 & \\
\hline
\end{tabular}


Table 2 Retail prices (excl. VAT) of adalimumab, etanercept, originator infliximab and biosimilar infliximab in some European countries on 1 April 2015

\begin{tabular}{|c|c|c|c|c|c|c|c|}
\hline \multirow[b]{2}{*}{ Active ingredient } & \multirow[b]{2}{*}{ Brand name } & \multirow[b]{2}{*}{ Volume, presentation } & \multicolumn{5}{|c|}{ Retail price (excl. VAT) } \\
\hline & & & France $(€)$ & UK $(\mathbf{f} / €)$ & Germany $(€)$ & Spain $(€)$ & Italy $(€)$ \\
\hline Adalimumab & Humira & $\begin{array}{l}40 \mathrm{mg} \\
\text { syringe or pen }\end{array}$ & 417.01 & $352.14 / 450.74$ & $\begin{array}{l}742.99 \text { (pack of } 2 \text { units) } \\
703.55 \text { (pack of } 6 \text { units) }\end{array}$ & 514.15 & 507.56 \\
\hline \multirow[t]{2}{*}{ Etanercept } & Enbrel & $\begin{array}{l}25 \mathrm{mg} \\
\text { syringe }\end{array}$ & 105.67 & $89.38 / 114.41$ & 175.89 & 118.40 & 121.19 \\
\hline & & $\begin{array}{l}50 \mathrm{mg} \\
\text { syringe or pen }\end{array}$ & 211.34 & $178.75 / 228.80$ & 351.78 & 236.81 & 242.38 \\
\hline Originator infliximab & Remicade & $\begin{array}{l}100 \mathrm{mg} \\
\text { vial }\end{array}$ & 434.40 & $419.62 / 537.11$ & 753.47 & 536.28 & 515.03 \\
\hline \multirow[t]{2}{*}{ Biosimilar infliximab } & Inflectra & $\begin{array}{l}100 \mathrm{mg} \\
\text { vial }\end{array}$ & 434.40 & $377.66 / 483.40$ & $\begin{array}{l}562.76 \text { (pack of } 5 \text { units) } \\
562.17 \text { (pack of } 4 \text { units) } \\
561.21 \text { (pack of } 3 \text { units) } \\
559.27 \text { (pack of } 1 \text { unit) }\end{array}$ & 439.75 & 386.28 \\
\hline & Remsima & $\begin{array}{l}100 \mathrm{mg} \\
\text { vial }\end{array}$ & 434.40 & $377.66 / 483.40$ & 603.00 & 439.75 & 386.28 \\
\hline
\end{tabular}

\section{Biosimilar scenarios}

Four different scenarios were described: a baseline scenario corresponding to the situation in 2012 when biosimilar infliximab was not yet available and all adult RA patients were treated with originator infliximab, and three biosimilar scenarios corresponding to different rates of uptake of biosimilar infliximab. These scenarios are as follows (figure 1):

- Baseline scenario: no biosimilar infliximab is available and all adult RA patients are treated with originator infliximab

- Biosimilar scenario 1 (extreme scenario): all patients treated with the originator infliximab are switched to the biosimilar

- Biosimilar scenario 2: only patients who start a new biological therapy are treated with biosimilar infliximab:

- Biosimilar scenario 2a: new patients who would have been treated with the originator infliximab are treated with the biosimilar infliximab

- Biosimilar scenario 2b: new patients who would have been treated with the originator infliximab, adalimumab or etanercept, are treated with the biosimilar infliximab

- Biosimilar scenario 3: switching the originator infliximab to biosimilar infliximab is allowed:
- Biosimilar scenario 3a: 30\% of patients currently treated with the originator infliximab are switched to its biosimilar

- Biosimilar scenario 3b: 50\% of patients currently treated with the originator infliximab are switched to its biosimilar

- Biosimilar scenario 3c: $80 \%$ of patients currently treated with the originator infliximab are switched to its biosimilar.

\section{Patient population}

The size of the patient' population with RA was estimated from our previous study, as well as the ratio of patients eligible for biological therapy. ${ }^{24}$ Those patients were defined as residing and being insured in Alsace under the general scheme managed by CNAMTS. They were at least 20 years of age or older and had RA classified as long-term disease no. 22 belonging to the French long-term diseases list for which CNAMTS provides $100 \%$ health insurance coverage. There were 5702 RA patients in Alsace in 2012, of whom 1075 (ie, 18.85\%) were receiving biotherapy treatment. Of these patients, $10.9 \%$ were treated with the originator infliximab, 26.4\% with adalimumab and

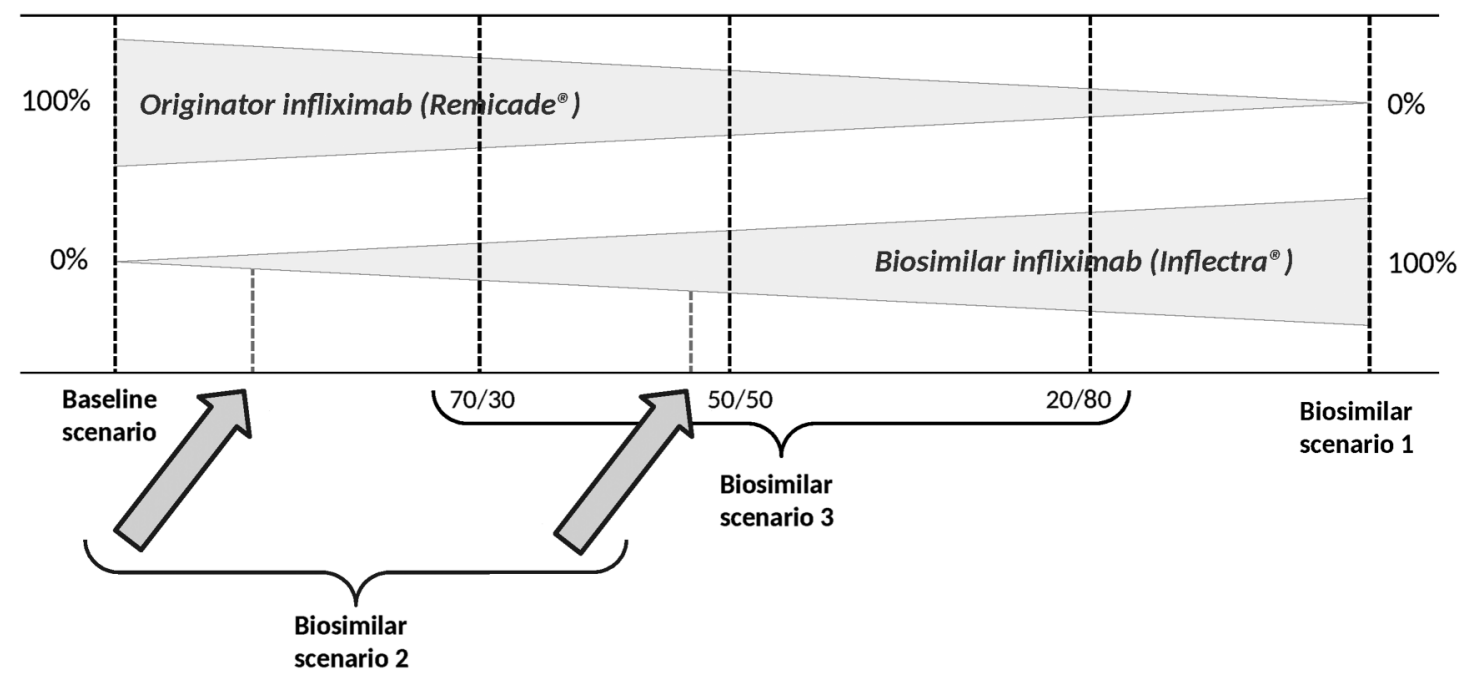

Figure 1 Biosimilar scenarios. 
$28.8 \%$ with etanercept, with no switching in 2012. ${ }^{24}$ The number of new RA patients in 2012 was estimated to be 651 in Alsace and 17323 in France, according to published incidence data on patients with RA classified as having long-term disease no. $22 .{ }^{25}$ We calculated the number of new patients who would likely be treated with biosimilar infliximab under 2012 prescribing practice. National extrapolations of savings and new patients who could be treated were calculated according to the following demographic information: 1861020 inhabitants of Alsace and 65542916 inhabitants of France. ${ }^{26}$

\section{Outcomes}

The primary outcomes of the study were the annual cost savings resulting from the introduction of biosimilar infliximab under different scenarios, and the number of additional patients who could be treated for 1 year with biosimilar infliximab, if all cost savings were used for this purpose. Microsoft Excel 2007 and R V.3.1.0 were used for calculations. The average annual costs per patient treated with adalimumab, etanercept, originator inflixi$\mathrm{mab}$ and biosimilar infliximab were compared using the Mann-Whitney U test. A p value below 0.05 was considered to be statistically significant.

\section{RESULTS}

\section{Updated costs to manage RA patients}

The 2015 costs for managing RA patients, calculated according to the 2015 updated prices (national retail prices and local biosimilar infliximab negotiated price) are presented in table 3 . The cost of biosimilar infliximab was very low compared to originator infliximab, etanercept and adalimumab, so that it involved a reversal in the distribution of annual average costs for RA patient care: inpatient care with biosimilar infliximab infusion in a hospital was significantly less expensive than outpatient care at home with subcutaneous adalimumab $(\mathrm{p}<0.01$, Mann-Whitney $\mathrm{U}$ test after matching based on age groups) or subcutaneous etanercept $(p<0.01$, Mann-Whitney $U$ test). The average annual costs of adalimumab and etanercept treatment were not significantly different from each other $(p=0.18$, Mann-Whitney $U$ test).

\section{Annual savings according to the different biosimilar scenarios}

In biosimilar scenario 1 (switching all patients from originator infliximab to biosimilar infliximab), the introduction of
Table 4 Estimated annual budget savings attributable to the introduction of biosimilar infliximab for the treatment of adult rheumatoid arthritis patients, according to three different scenarios

\begin{tabular}{lcr}
\hline Scenarios & $\begin{array}{l}\text { Annual savings } \\
\text { in Alsace }(€)\end{array}$ & $\begin{array}{r}\text { Annual savings } \\
\text { in France }(€)\end{array}$ \\
\hline Baseline scenario & 0 & 0 \\
Biosimilar scenario 1 & 385642 & 13581854 \\
Biosimilar scenario 2a & 38918 & 1370646 \\
Biosimilar scenario 2b & 112874 & 3975288 \\
Biosimilar scenario 3a & 115693 & 4074570 \\
Biosimilar scenario 3b & 192821 & 6790926 \\
Biosimilar scenario 3c & 308514 & 10865497 \\
\hline
\end{tabular}

biosimilar infliximab could lead to substantial annual cost savings of up to $€ 13.6$ million nationally. Only treating infliximab-naïve RA patients with biosimilar infliximab (biosimilar scenario 2) could result in significant savings especially if patients who would have been treated at home with subcutaneous biotherapies were treated in hospital with the biosimilar drug. Similarly, there would be a greater reduction in cost if originator infliximab were replaced with its biosimilar (biosimilar scenario 3) (table 4). If the costs saved nationally were used to treat additional patients, under the different scenarios 115-1141 new patients could be treated for 1 year with biosimilar infliximab (table 5). In the optimal scenario, the savings would enable 32 out of 651 (4.9\%) new RA patients in Alsace to be treated, and 1141 out of 17323 $(6.6 \%)$ patients nationally to be treated.

\section{DISCUSSION}

This study aimed to estimate cost savings associated with the introduction of biosimilar infliximab for RA patients in Alsace and in France, in a real-life setting through the use of health claims databases. We demonstrated a possible annual cost saving of $€ 13.6$ million at a national level if all adult patients with RA treated with originator infliximab switched to the biosimilar drug. The resulting cost savings could be used to treat an extra 1141 patients.

Some authors have previously estimated the cost savings that would accrue from the introduction of biosimilar infliximab. ${ }^{19-23}$ Their financial analyses are not comparable with our study due to

Table 3 Annual average costs for biotherapy acquisition and care for a rheumatoid arthritis patient with adalimumab, etanercept, originator infliximab or biosimilar infliximab: 2012 and 2015 calculated costs (data from the Alsace population ${ }^{24}$ )

\begin{tabular}{|c|c|c|c|c|}
\hline \multirow[b]{2}{*}{ Biotherapy } & \multicolumn{2}{|c|}{$\begin{array}{l}\text { Annual average cost }(€) \text { for biotherapy } \\
\text { acquisition to treat a single rheumatoid arthritis } \\
\text { patient (mean } \pm \text { SD) }\end{array}$} & \multicolumn{2}{|c|}{$\begin{array}{l}\text { Annual average cost }(€) \text { to support a rheumatoid } \\
\text { arthritis patient, including direct medical and } \\
\text { non-medical costs* (mean } \pm \text { SD) }\end{array}$} \\
\hline & Data 2012 & 2015 Calculated costs & Data 2012 & 2015 Calculated costs \\
\hline $\begin{array}{l}\text { Adalimumab } \\
\text { (Humira) }\end{array}$ & $11630 \pm 2356$ & $10495 \pm 2126$ & $14116 \pm 3736$ & $12981 \pm 3602$ \\
\hline $\begin{array}{l}\text { Etanercept } \\
\text { (Enbrel) }\end{array}$ & $11437 \pm 2669$ & $10650 \pm 2486$ & $14338 \pm 4187$ & $13551 \pm 4081$ \\
\hline $\begin{array}{l}\text { Originator infliximab } \\
\text { (Remicade) }\end{array}$ & $10345 \pm 5125$ & $9311 \pm 4613$ & $16480 \pm 6677$ & $15445 \pm 6288$ \\
\hline $\begin{array}{l}\text { Biosimilar infliximab } \\
\text { (Inflectra) }\end{array}$ & - & $5773 \pm 2860$ & - & $11907 \pm 5120$ \\
\hline
\end{tabular}


Table 5 Additional rheumatoid arthritis patients who could be treated for 1 year if the savings were spent on biosimilar infliximab

\begin{tabular}{lcc}
\hline Scenarios & $\begin{array}{c}\text { Extra patients who could } \\
\text { be treated in Alsace }\end{array}$ & $\begin{array}{l}\text { Extra patients who could } \\
\text { be treated in France }\end{array}$ \\
\hline Baseline scenario & 0 & 0 \\
Biosimilar scenario 1 & 32 & 1141 \\
Biosimilar scenario 2a & 3 & 115 \\
Biosimilar scenario 2b & 9 & 334 \\
Biosimilar scenario 3a & 10 & 342 \\
Biosimilar scenario 3b & 16 & 570 \\
Biosimilar scenario 3c & 26 & 913 \\
\hline
\end{tabular}

differences in methodology and in settings, but the conclusions are similar. For example, the study by Brodszky et al showed that the introduction of biosimilar infliximab in six Central and Eastern European countries could lead to substantial cost saving of $€ 15.3$ million to $€ 20.8$ million over a 3 -year period, depending on the scenario envisioned. ${ }^{19}$ In 2015 , Jha et al ${ }^{20}$ considered the impact over 1 year of the introduction of biosimilar infliximab in five European countries for the treatment of inflammatory autoimmune diseases (RA, ankylosing spondylitis, Crohn's disease, ulcerative colitis, psoriasis and psoriatic arthritis) and showed cumulative cost saving of $€ 77.37$ million with a $30 \%$ discount. Another study carried out by Kim et al found total 5-year savings of $€ 96$ million to $€ 433$ million for the management of RA across the UK, Italy, France and Germany. ${ }^{23}$

The main advantage of our study is that the retail price of biosimilar infliximab and its negotiated price were available at the time of the analysis, unlike other studies that had to estimate the discount rate. ${ }^{19} 20$ Such information was key since the negotiated biosimilar price was the main factor influencing the financial impact. Although the French price of the originator infliximab (Remicade) and biosimilar infliximab (Inflectra) are currently the same (€434.40), cost savings can be made through cost negotiation. Indeed, hospitals belonging to UniHA obtained a $38 \%$ lower negotiated price for Inflectra (€269.33 vs $€ 434.40)$. This additional discount leads to tangible cost savings. Furthermore, real-life figures on the number of RA patients and number of vials of infliximab used to treat each patient in Alsace were supplied from a previous study, and so avoided estimations on the prevalence of the disease, the patients' weight and the dosage prescribed. ${ }^{24}$

Nevertheless, our analysis has some limitations, mainly due to the assumptions we had to make. In scenario $2 b$, the study did not consider patients who switched from a biotherapy other than infliximab, adalimumab or etanercept (eg, abatacept, certolizumab, golimumab, rituximab, tocilizumab or anakinra) to the biosimilar infliximab or patients who switched from one biotherapy to another within a year. Patients were regarded as being treated for a full year with biosimilar infliximab without considering the progressive transition from a previous biotherapy to the biosimilar infliximab, or initiation of biosimilar treatment in a biotherapy-naïve patient at any time during the year. We also assumed prescribing practices were the same in both Alsace and the rest of France (number of RA patients under biological therapy, percentage of patients treated with originator infliximab, adalimumab and etanercept) in order to extrapolate cost savings to a national level.

Our results reflect various possible scenarios and should be interpreted with caution, as framing recommendations for biosimilar interchangeability and/or substitution are outside the remit of the EMA and differ according to the national competent authority in each European Union member state. ${ }^{27}$ Indeed, in France, biosimilar treatment is only currently recommended in biologic-naïve patients, and the French regulatory framework is still pending. Prescribers still have to consider whether it is appropriate to start a new treatment with a biosimilar or to switch from the originator to the biosimilar drug.

The study focused on RA, but many other medical fields are or will be involved in the future (eg, biosimilar insulins in diabetes or biosimilar trastuzumab, bevacizumab or cetuximab in oncology). Biosimilar infliximab is just one example of many other biosimilar drugs that will soon become available and so this study reflects only some of the total cost saving that will be achievable. ${ }^{18} 28-30$

\section{CONCLUSION}

The study showed the beneficial financial impact of introducing biosimilar infliximab for the treatment of adult RA patients in Alsace and in France. Such savings can contribute to improved patient care through the reallocation of budgets so that more patients can be treated and affordable treatment accessed by more patients. As infliximab is exclusively reserved for hospital use, a gradual change from outpatient to inpatient care is likely to occur, until the arrival of subcutaneous biosimilars which can be administered at home. This paradigm shift must be taken into account as regards the organisation and development of day hospital services.

\section{Key messages}

What is already known on this subject

- Biologic treatments are highly effective for the treatment of rheumatoid arthritis, but are very expensive and significantly increase the economic burden associated with this disease.

- Biosimilar drugs are cheaper, very similar 'copies' of biological drugs whose patents have expired, and have equivalent quality, safety and efficacy.

- Some budget impact analyses based upon the discounted rate of the biosimilar and using theoretical statistical models only, have demonstrated the cost saving potential of using biosimilar infliximab.

\section{What this study adds}

- The present study demonstrates a positive financial impact from the introduction of biosimilar infliximab for the treatment of adult patients with rheumatoid arthritis in Alsace and in France.

- Such savings can benefit overall patient care by allowing more patients to be treated without more money being spent.

Acknowledgements The authors are grateful to Pascal Lallemand, Pascale Willem and Bérangère Pierre for extracting the 2012 anonymised and aggregated data on the management of patients with rheumatoid arthritis, and to Rama Piotto for proofreading and linguistic review of the manuscript.

Contributors All authors have contributed significantly to the publication. All authors have read and approved the submitted manuscript.

Competing interests CS reports personal fees from Abbvie, Lilly, MSD, Pfizer and Roche, outside the submitted work; JS reports consulting and speaking fees from Abbott, Abbvie, Actelion, Amgen, BMS, Chugai, GSK, Hospira, LFB, MSD, Novartis, Pfizer, Roche and UCB, outside the submitted work.

Provenance and peer review Not commissioned; externally peer reviewed. 


\section{REFERENCES}

1 Singh JA, Furst DE, Bharat A, et al. 2012 Update of the 2008 American College of Rheumatology recommendations for the use of disease-modifying antirheumatic drugs and biologic agents in the treatment of rheumatoid arthritis: 2012 ACR RA Treatment Recommendations. Arthritis Care Res 2012;64:625-39.

2 Gaujoux-Viala C, Gossec L, Cantagrel A, et al. Recommendations of the French Society for Rheumatology for managing rheumatoid arthritis. Joint Bone Spine 2014;81:287-97.

3 Ramiro S, Gaujoux-Viala C, Nam JL, et al. Safety of synthetic and biological DMARDs: a systematic literature review informing the 2013 update of the EULAR recommendations for management of rheumatoid arthritis. Ann Rheum Dis 2014;73:529-35.

4 Nam JL, Ramiro S, Gaujoux-Viala C, et al. Efficacy of biological disease-modifying antirheumatic drugs: a systematic literature review informing the 2013 update of the EULAR recommendations for the management of rheumatoid arthritis. Ann Rheum Dis 2014;73:516-28.

5 Schoels M, Wong J, Scott DL, et al. Economic aspects of treatment options in rheumatoid arthritis: a systematic literature review informing the EULAR recommendations for the management of rheumatoid arthritis. Ann Rheum Dis 2010;69:995-1003.

6 Smolen JS, Landewé R, Breedveld FC, et al. EULAR recommendations for the management of rheumatoid arthritis with synthetic and biological disease-modifying antirheumatic drugs: 2013 update. Ann Rheum Dis 2014;73:492-509.

7 Michaud K, Messer J, Choi HK, et al. Direct medical costs and their predictors in patients with rheumatoid arthritis: a three-year study of 7,527 patients. Arthritis Rheum 2003;48:2750-62.

8 Ruof J, Hülsemann JL, Mittendorf T, et al. Costs of rheumatoid arthritis in Germany: a micro-costing approach based on healthcare payer's data sources. Ann Rheum Dis 2003;62:544-9.

9 Juillard-Condat B, Constantin A, Cambon-Thomsen A, et al. Impact of etanercept on the costs of rheumatoid arthritis (RA): results from a French observational study. Joint Bone Spine 2008;75:25-8.

10 Kalkan $A$, Hallert $E$, Bernfort $L$, et al. Costs of rheumatoid arthritis during the period 1990-2010: a register-based cost-of-illness study in Sweden. Rheumatol Oxf Engl 2014;53:153-60.

11 Weise M, Bielsky M-C, De Smet K, et al. Biosimilars: what clinicians should know. Blood 2012;120:5111-17.

12 European Medicines Agency (EMA). Guideline on similar biological medicinal products. 2014. http://www.ema.europa.eu/docs/en_GB/document_library/Scientific guideline/2014/10/WC500176768.pdf (accessed 21 Apr 2015).

13 European Medicines Agency (EMA). Guideline on similar biological medicinal products containing monoclonal antibodies-non-clinical and clinical issues. 2012 http://www.ema.europa.eu/docs/en_GB/document_library/Scientific_guideline/2012/ 06/WC500128686.pdf (accessed 29 Oct 2015).

14 Yoo DH, Hrycaj P, Miranda P, et al. A randomised, double-blind, parallel-group study to demonstrate equivalence in efficacy and safety of CT-P13 compared with innovator infliximab when coadministered with methotrexate in patients with active rheumatoid arthritis: the PLANETRA study. Ann Rheum Dis 2013;72:1613-20.
15 Baji P, Péntek M, Czirják L, et al. Efficacy and safety of infliximab-biosimilar compared to other biological drugs in rheumatoid arthritis: a mixed treatment comparison. Eur J Health Econ HEPAC Health Econ Prev Care 2014;15(Suppl 1): S53-64.

16 Isaacs JD, Cutolo M, Keystone EC, et al. Biosimilars in immune-mediated inflammatory diseases: initial lessons from the first approved biosimilar anti-tumour necrosis factor monoclonal antibody. J Intern Med 2016;279:41-59.

17 Gulácsi L, Brodszky V, Baji P, et al. Biosimilars for the management of rheumatoid arthritis: economic considerations. Expert Rev Clin Immunol 2015;11(Suppl 1):43-52.

18 Haustein R, de Millas C, Höer A, et al. Saving money in the European healthcare systems with biosimilars. Generics Biosimilars Initiat J 2012;1:120-6.

19 Brodszky V, Baji P, Balogh O, et al. Budget impact analysis of biosimilar infliximab (CT-P13) for the treatment of rheumatoid arthritis in six Central and Eastern European countries. Eur J Health Econ HEPAC Health Econ Prev Care 2014;15(Suppl 1):S65-71.

20 Jha A, Upton A, Dunlop WC, et al. The budget impact of biosimilar infliximab (Remsima $®$ ) for the treatment of autoimmune diseases in five European countries. Adv Ther 2015:32:742-56.

21 McCarthy G, Ebel Bitoun C, Guy H. Introduction of an infliximab biosimilar (CT-P13): a five-year budget impact analysis for the treatment of rheumatoid arthritis in Ireland. Value Health 2013;16:A558.

22 Lucioni C, Mazzi S, Caporali R. Budget impact analysis of infliximab biosimilar: the Italian scenery. Glob Reg Health Technol Assess 2015;2:78-88.

23 Kim J, Hong J, Kudrin A. 5 Year budget impact analysis of biosimilar infliximab for the treatment of rheumatoid arthritis in UK, Italy, France and Germany. Arthritis Rheumatol 2014;11:S512 (abstract 1166).

24 Beck M, Velten M, Rybarczyk-Vigouret M-C, et al. Analysis and breakdown of overall 1-year costs relative to inpatient and outpatient care among rheumatoid arthritis patients treated with biotherapies using health insurance claims database in Alsace. Drugs—Real World Outcomes 2015;2:205-15.

25 Assurance maladie (Ameli). ALD 30 en 2012-incidence. http://www.ameli.fr/ I-assurance-maladie/statistiques-et-publications/donnees-statistiques/ affection-de-longue-duree-ald/incidence/ald-30-en-2012.php (accessed 29 Oct 2015)

26 Institut national de la statistique et des études économiques (Insee). Données détaillées de la situation démographique en 2013. http://www.insee.fr/fr/themes/ detail.asp?ref_id=ir-irsocsd2013\&page=irweb/irsocsd2013/dd/irsocsd2013_ population.htm (accessed 29 Oct 2015).

27 European Commission. What you need to know about biosimilar medicinal products -A consensus information document. 2013. http://ec.europa.eu/DocsRoom/ documents/8242/attachments/1/translations/en/renditions/native (accessed 30 Oct 2015).

28 Henry D, Taylor C. Pharmacoeconomics of cancer therapies: considerations with the introduction of biosimilars. Semin Oncol 2014;41(Suppl 3):S13-20.

29 Polimeni G, Trifirò $G$, Ingrasciotta $Y$, et al. The advent of biosimilars for the treatment of diabetes: current status and future directions. Acta Diabetol 2015;52:423-31

30 DeVries JH, Gough SCL, Kiljanski J, et al. Biosimilar insulins: a European perspective. Diabetes Obes Metab 2015;17:445-51. 